\title{
Information Seeking Behaviors of Children and Youth: Challenges and Implications for Information Literacy Instruction \\ A Review of the Literature
}

\author{
Clayton A. Copeland \\ Ph.D. Student \\ University of South Carolina \\ USA
}

\begin{abstract}
Research indicates that technological advances are changing the ways people are searching for, finding, and using information for personal, professional, and educational purposes (Bernier, 2007; Heath, 2007; Perrault, 2007). Human information behavior encompasses people's information needs, information seeking behaviors, information contexts, patterns of information access, retrieval, processing, and use (Todd, 2003).
\end{abstract}

An emerging area of human information behavior is the information seeking practices of youth. Research suggests the need for educators to adapt instruction and refine students' Information Seeking skills and foster advanced information literacy (Branch, 2003; Dixon \& Shenton, 2005; Kulthau, 1994, 2003; Hultgren and Limberg, 2002; Laverty, 2003; Leu and Kinzer, 2000; and McGregor, 1994).

Information seeking behaviors, Information Literacy Instruction

\section{Introduction}

Research indicates that technological advances are changing the ways people are searching for, finding, and using information for personal, professional, and educational purposes (Bernier, 2007; Bilal, 2001; Heath, 2007 and Perrault, 2007). Human information behavior encompasses people's information needs, information seeking behaviors, information contexts, and patterns of information access, retrieval, processing, and use (Todd, 2003).

An emerging area of human information behavior encompasses people's information needs is the information seeking practices of children and youth. Research suggests the need for educators to adapt instruction to refine students' information seeking skills and to foster advanced information literacy (Branch, 2003; Dixon and Shenton, 2005; Kulthau, 1994, 2003; Hultgren and Limberg, 2003; Laverty, 2002; Leu \& Kinzer, 2000; Leu, Kinzer, Coiro, \& Cammack, 2004; and McGregor, 1994). Critical findings from the literature, for instance, indicate that (a) cognitive, emotional, and social development levels impact the information seeking skills and strategies of children and youth (Gross, 2000; McGregor, 1994); and (b) levels of skill practice and Information System design impact the overall effectiveness of children's and youth's Information Seeking skills. Findings also indicate that adults may fail to recognize or take into account the differences between the Information Seeking behaviors of children and youth and their own Information Seeking behaviors (McGregor, 1994).

Finally, the literature indicates that proper instruction and instructional intervention(s) are critical for student mastery of Information Literacy and Information Seeking skills. In order to employ appropriate instructional strategies that best meet the needs of today's children and youth, it is essential that educators first develop awareness of whom these children and youth 
are and are their developmental stages, their unique information needs and demands, and their information seeking behaviors. Accordingly, the purposes of this literature review are to provide a profile of Generation Y (students born between 1980 and 1994) as it pertains to their information needs and information seeking behaviors; to identify the nature and scope of Information Seeking behaviors among children and youth; to identify instructional strategies available to educators and librarians to better meet child and youth information needs; and to identify research areas warranting further exploration.

\section{Profile of Generation Y: Engaged in Multimodal Literacies}

Unprecedented advances in technology are requiring users of information to reconsider and even reformulate the ways they find, analyze, synthesize, and use information (Bernier, 2007; Bilal, 2001; Heath, 2007; and Perrault, 2007). A Pew Research Foundation study (2005) asserts, "Today's American teens live in a world enveloped by communications technologies; the internet and cell phones have become a central force that fuels the rhythm of daily life" (n.p.). The National Council of Teachers of English (2005) supports the assertion and makes its own claim that, "learning is increasingly defined by multimodal literacies" (n.p.). Technology is requiring today's students (Generation Y, or those students born between 1980 and 1994, and beyond) to acquire skill sets which surpass "traditional" research strategies and move into previously unknown territories and use a culmination of print, electronic, and digital media to create information products.

\section{Literature Reveals Differing Perspectives}

Amid changes in information and in Information Seeking behaviors, there have also been differing perspectives or opinions regarding the effectiveness of Information Seeking behaviors among children and youth. While some educators posit beliefs that children and youth possess strong Information Literacy and Information Seeking skills, others question students' Information Literacy and Information Seeking skills.

Linking educators' concerns regarding Generation Y's Information Seeking skills to commentary among researchers and academe (Weiler, 2005) cited several criticisms of Information Seeking skills among children and youth. The first of the criticism surrounds the idea that student critical thinking and other cognitive skills (not to mention physical wellbeing) are suffering from the large proportions of time children and youth are devoting to sedentary pastimes and passive absorption of words and images. Sedentary pastimes and over reliance on "copying and pasting" information, critics argue, are robbing the nation's youngest information seekers of time that should be spent reading and engaging in creative, critical thinking. The group argues that Generation Y students, in particular, have a seeming lack of regard for research and for the procurement of skills that our society has previously deemed imperative for successful knowledge development. It further appears, according to the group, that Generation Y students lack both intrinsic and extrinsic motivation to complete tasks and are consequently trading traditional research processes and (even more significantly), critical thought and inquiry for the quickest and easiest route to solving information problems. Rather than scouring peer-reviewed, scholarly sources in search of information or working to gain in-depth knowledge and understanding a topic, today's students are opting for so-called quick and easy alternatives, including now-infamous Internet searches, and even casual chats with friends and peers (especially the peers and friends with whom the students feel they are likely to find commonality of opinion) (Weiler, 2005). 
Meanwhile, citing evidence from educators who believe that children's and youth's information seeking skills are strong, Joy McGregor (1994), questioned critics' assertions of weakness among today's young information seekers and poses the following question: Is it really possible that technology and the need to be "connected" to these technologies are usurping intrinsic motivation and critical thinking skills? Or is it possible that while students do in fact engage in critical thinking, their thought patterns differ from those "experts" typically associate with critical thinking among adults and are therefore somehow overlooked? In McGregor's research, findings indicate that students do indeed engage in critical thinking and inquiry but that the thought patterns are not always recognized as such because thinking is typically an intuitive process for students at various levels of cognitive levels. Thusly, students are often unaware of their own critical thinking efforts and may fail to acknowledge methods of thinking which could be more productive. Such findings, McGregor asserts, could lead to the conclusion that student failure to think critically does not reflect an absence of willingness or ability to engage in critical inquiry. Instead, the author finds that a failure to engage in critical thinking could be linked to cognitive development. In the same study, McGregor also found that "the nature of questions instructors asked in assignments influenced the complexity of thought involved in using the information" (1994, p. 74). The finding that what educators or researchers perceive to be a lack of critical thinking or an inability of students to think critically is may in fact be a lack of skill or an inability of educators to formulate clear, stimulating questions.

Also an advocate for youth and a proponent of the belief that children and youth have strong Information Seeking skills, Anthony Bernier (2007) credits the "changing face of information" with discrediting youth Information Seeking abilities and skill levels. Bernier asserts the possibility that, in educators' efforts to understand children and youth and their Information Seeking behaviors in academic settings, we have somehow reduced young people to "one dimensional beings" who lack depth or are intellectually inferior to their predecessors. Then, citing studies from the Pew Research Foundation (2005), the author postulates that technology is changing the face of information and is requiring that people change the ways we disseminate and use information. As the generation proving themselves to be the most familiar with and most adept at using emerging technologies, Bernier believes, youth are among the most capable of seekers and users of information. Furthering his point, the author identifies today's youth as the new leaders of information. He goes so far as to say that any perceived skill weaknesses among the group are consequences not of substandard critical thinking skills or "laziness," but rather a lack of understanding from older generations regarding the "new face of information" and the new definition of effective information seeking.

Taking the findings of these youth advocates into account, it is plausible that, in our own efforts to label and disseminate information seeking among youth, we (educators) fail to consider students' individual, cognitive, developmental, social, and cultural needs of our students. Because the face of information and Information Seeking behaviors are changing at such drastic levels, it is also possible that our own insecurities over changes in the Information Age have contributed to misunderstandings of what Information Seeking requires and to misunderstandings of what effective Information Seeking skills or strategies require. Dixon and Shenton (2005) suggest that criticisms of children's and youth's Information Seeking skills result from a lack of understanding among older generations of what children and youth want, need, and expect from research. 


\section{Key Findings from the Literature: The New Face of Information Brings Attention to the Need for a New face for Information Literacy Instruction}

In their research, Branch (2003) and Kulthau (1994) indicate that proper instruction and instructional intervention(s) are critical for student mastery of Information Literacy and Information Seeking skills. Multiple components contribute to effective Information Literacy and Information Seeking instruction, including: (a) educators' understanding of students' cognitive, emotional, and social developmental levels (Gross, 2000; McGregor, 1994); (b) effective integration of practice and hands-on activities; (c) adult / educator recognition that the Information Literacy and Information Seeking behaviors of children and youth differ from their own (McGregor, 1994). Dixon and Shenton (2005) assert that the first step to effective Information Literacy and Information Seeking skill instruction is educators' understanding of what children and youth want, need, and expect from research. Secondly, identifying how Information Literacy is to be achieved within curriculum guidelines is critical (Laverty, 2002; Small, 1998). Bilal $(2000,2001)$ found that appropriate system design (i.e., implementing system design in Web search engines is critical to information seeking among children) and advocated changes in system design to better meet children's developmental needs. Meanwhile, Kulthau (1994; 2003), Laverty (2002), Small (1998) and Todd (2003) all identified additional specific instructional strategies available to educators and librarians to better meet youth information needs.

Identifying several well-established theories and concepts of motivation and applying them to Information Literacy Instruction, Small stressed how imperative stimulating students' intellectual curiosity and awakening students' desires to seek information are to effective instruction. According to Small, when educators employ intrinsic motivators in instruction (i.e. explain the importance of a learning task to students or help them relate the learning task to their personal needs and experiences), there is typically a higher rate of on-task behavior. In accordance with other findings of her study and studies she cites, Small also suggests the following instructional strategies: (a) focus on student effort and ability and use research skills to achieve related learning objectives; (b) create an environment that is both supportive and challenging for students but that matches challenges to one's skill level; (c) reduce student anxiety levels, thereby freeing students to maintain focus on the task at hand; (d) provide meaningful learning objectives; (d) maintain student expectations for success; and (e) match extrinsic and intrinsic motivators to student developmental levels. Kulthau (2003) and Laverty (2002) advocated engaging students in inquiry-based and resource-based learning and activities. Finally, and perhaps most significantly, Kulthau, 1994, 2003; Small, 1998; and Todd, 2003, stressed the importance of collaborative planning and implementing lessons with the classroom teacher and / or the school library media specialist.

\section{Conclusions and Areas for Future Research}

Technological advances in the Information Age are changing the ways people are searching for, finding, and using information for personal, professional, and educational purposes (Bernier, 2007; Bilal, 2000, 2001; Heath, 2007; and Perrault, 2007). Thusly, it is becoming increasingly apparent that educators must adapt instruction to refine students' Information Seeking skills and foster advanced Information Literacy (Branch, 2003; Dixon and Shenton, 2005; Kulthau, 1994, 2003; Laverty, 2002; Hultgren \& Limberg, 2003; Leu \& Kinzer, 2000; 
Leu, Kinzer, Coiro, \& Cammack, 2004; and McGregor, 1994). Perhaps Dervin and Nilan stated conveyed this reality most eloquently of all when they said, "It becomes increasingly clear that the success of information services is more likely to be achieved through adjusting the services to meet the specific needs of an individual rather than trying to adapt the individual user to match the wholesale output of the information system" (Dervin and Nilan, 1986, p. 7, as cited by Todd, 2003). Accordingly, areas of future research could include the following: (a) the effects of pre-service and continuing education on instructional effectiveness; and (b) Information Seeking and Information Literacy instructional strategies for differently able children and youth.

\section{References}

Bernier, A. (2007). Introduction: "Not broken by someone else's schedule: On joy and young adult information seeking." In M. K. Chelton \& C. Cool (Eds.), Youth information-seeking behavior II: Context, theories, models, and issues (pp. xiii-xxviii) [Introduction]. Lanham, MD: Scarecrow Press, Inc.

Bilal, D. (2000). "Children's use of Yahooligans! web search engine: I. Cognitive, physical, and affective behaviors on fact-based search tasks." Journal of the American Society for Information Science 51(7): 646655

Bilal, D. (2001). "Children's use of Yahooligans! web search engine: II. Cognitive and physical behaviors on research tasks." Journal of the American Society for Information Science and Technology 52(2): 118-136

Branch, J. L. (2003). "Instructional intervention is key: Supporting adolescent Information Seeking." School Libraries Worldwide 9(2): 47-61

Gross, M. (2000). The imposed inquiry and information services for children. Journal of Youth Services in Libraries, 13(2), 10-17

Heath, F. (2007). The impact of evolving information-seeking behaviors upon research libraries: A case study. Journal of Library Administration, 46(2), 3-16

Hultgren, F. \& Limberg, L. (2003). “A study of research on children's information behaviour in a school context." New Review of Information Behaviour Research 4(1): 1-15

Kuhlthau, C. C. (2003). "Rethinking libraries for the Information Age school: Vital roles in inquiry learning." School Libraries in Canada 22(4): 3-5

National Council of Teachers of English (2005). Multimodal Literacies. Retrieved December, 15, 2007 from http://www.ncte.org/about/over/positions/category/media/123213.htm

Laverty, C. (2002). "The challenge of Information Seeking: How children engage in library work." Feliciter 48(5): $226-228$

Leu, D.J., Jr. \& Kinzer, C.K. (2000). "The convergence of literacy instruction with networked technologies for information and communication. Reading Research Quarterly, 35, 108-127.

Leu, D.J., Kinzer, C.K., Coiro, J.L. and Cammack, D.W. (2004). Toward a theory of new literacies emerging from the Internet and other information and communication technologies In R. B. R. a. N. J. Unrau (Ed.), Theoretical Models and Processes of Reading (5th ed., pp. 1570-1613): International Reading Association.

Pew Internet \& American Life Project (2005). Teens and Technology. Retrieved December 15, 2007 from http://www.pewinternet.org/topics.asp?c=4

Shenton, A. K., \& Dixon, P. (2005, Summer/Fall). Information Needs: Learning More about what Kids Want, Need, and Expect from Research. Children and Libraries: The Journal of the Association for Library Service to Children, 3(2), 20-28 
Small, R. V. (1999). An exploration of motivational strategies used by library media specialists during library and information skills instruction. School Library Media Research, 2

Todd, R. J. (2003). "Adolescents of the Information Age: Patterns of Information Seeking and use, and implications for information professionals." School Libraries Worldwide 9(2): 27-46

Weiler, A. (2005). "Information-Seeking behavior in Generation Y Students: Motivation, critical thinking, and learning theory." Journal of Academic Librarianship 31(1): 46-53

\section{Biographical Notes}

Clayton A. Copeland is currently a Ph.D. student at the University of South Carolina's School of Library and Information Science. First inspired by her elementary school librarian, Clayton's current research and research interests involve library services to children and youth, information seeking behaviors of children and youth, and library services to differently-able populations and underserved populations.

\section{Statement of Originality}

This statement certifies that the paper above is based upon original research undertaken by the author and that the paper was conceived and written by the author(s) alone and has not been published elsewhere. All information and ideas from others is referenced. 